Stručni članak

Primljeno: veljača, 2014.

Prihvaćeno: ožujak, 2014.

UDK 159.922.7: 347.627 .2

DOI 10.3935/ljsr.v21i1

Ljubica Hajnić

\section{SINDROM OTUĐENJA OD RODITELJA}

\section{SAŽETAK}

Ovaj rad bavi se temom sindroma otuđenja od roditelja tijekom i nakon razvoda braka kao posljedice sukoba među partnerima. Kroz analizu slučaja prikazati će se kako roditelj, partner koji se teže nosi s odlukom o razvodu braka pokušava svoju ljutnju, razočarenje i povredu prenijeti na dijete/djecu te se na taj način osvetiti partneru i otuđiti ga od djece. Također će se problematizirati teškoće oko dokazivanja takvog ponašanja na sudu kao i mogućnosti suzbijanja takvog ponašanja (pravne posljedice).

I Ljubica Hajnić, prof. psihologije, e-mail: ljubica.hajnic@gmail.com
Centar za socijalnu skrb Zagreb PodružnicaDubrava

Ključne riječi:

sindrom otuđenja, razvod braka, djeca. 


\section{UVOD}

Razvod braka za obitelj u kojoj se događa stresno je iskustvo, koje kod većine djece i roditelja koji su suočeni sa zahtjevima za prilagodbu novonastalim uvjetima života izaziva intenzivne emocionalne reakcije. Neki roditelji, unatoč vlastitim emocionalnim reakcijama tijekom razvoda, imaju kapaciteta i nalaze načina djetetu pružiti potrebnu podršku.

Nažalost, neki od njih se i sami teško suočavaju s činjenicom razvoda braka, ne preuzimaju odgovornost za odnos s djetetom i bivšim partnerom, čime razvod braka za djecu postaje još teže i zahtjevnije iskustvo. U takvim situacijama dijete i njegove potrebe, kao i emocionalne reakcije na roditeljski sukob i razvod braka, ostaju neprepoznate, a dijete uskraćeno za potrebnu podršku.

Djecu dodatno opterećuje uključivanje drugih odraslih članova obitelji u bračni sukob (najčešće baka i djedova djece, braće i sestara roditelja - osoba na čiju podršku dijete može računati u nekim drugim stresnim životnim situacijama), stoga postoji rizik da dijete u takvim obiteljima ostane posve samo i nevidljivo. $U$ takvim je situacijama osobito važno (kada je to već izostalo u obitelji) da djetetovo emocionalno stanje i njegove potrebe budu prepoznate od strane stručnjaka s kojima dolazi u toj fazi života u kontakt - psihologa i socijalnog radnika u centru za socijalnu skrb, odgajatelja i stručnih suradnika u predškolskoj ustanovi ili učitelja, profesora i stručnih suradnika u školi. Oni djetetu mogu postati izvor podrške, a istodobno i korektiv roditeljskih reakcija te preuzeti odgovornost za savjetovanje i rad s roditeljima kako bi oni počeli bolje sagledavati potrebe djeteta i ponašati se odgovorno u roditeljskoj ulozi, bez obzira na vlastite snažne čuvstvene reakcije na razvod braka (Profaca, 2010.; Ernečić i Patrčević, 2013.).

Najučestaliji oblici manipulacije pravima djeteta odnose se na kršenja prava djece na kontinuirani razvoj odnosa s oba roditelja nakon razvoda braka, iako je procijenjeno da su susreti i druženja u interesu djeteta (zajamčeno čl. 9. st. 3. Konvencije o pravima djeteta i čl. 87. st. 3. ObZ) te na pokušaj otuđenja djeteta od drugog roditelja. Pri tome se manipulativni oblici ponašanja mogu uočiti kod roditelja s kojim dijete ostaje živjeti, kao i kod roditelja s kojim se dijete susreće i druži. Riječ je o nizu ponašanja, verbalnih i neverbalnih poruka roditelja, koji djetetu šalju negativnu poruku o drugom roditelju s ciljem njegova isključivanja iz života djeteta i otuđivanja djeteta od roditelja, iako za to ne postoji razlog koji proizlazi iz odnosa roditelja i djeteta (Jelavić, 2010.).

Richard A. Gardner (1985., prema Warshak, 2008.) uvodi termin »sindrom otuđenja od roditelja« (eng. Parental Alienation Syndrom - PAS), a odnosi se na poteškoće koje manifestiraju djeca zbog svjesnog ili nesvjesnog ponašanja jednog roditelja. Gardner navodi 8 manifestacija PAS-a u dječjem ponašanju:

\section{8 iskustva iz prakse}


1. kampanja ocrnjivanja - navode da mrze jednog roditelja, te negiraju sva pozitivna iskustva koja su imali s tim roditeljem, iako su ga prije voljeli

2. apsurdni razlozi i racionalizacije za odbacivanje roditelja - kao razloge za odbacivanje roditelja često navode beznačajne stvari poput nekih njegovih navika i sl.

3. nedostatak ambivalencije prema roditelju koji otuđuje - jednog roditelja vide kao savršenog, bez ijedne mane, a drugog kao apsolutno lošeg, te o njemu navode samo mane

4. fenomen »nezavisnog mislitelja«- inzistiraju da su njihove odluke samo njihove, naglašavaju svoju volju u odlučivanju i postupanju prema roditelju kojeg odbijaju, te tvrde da nitko nije na njih utjecao

5. nedostatak krivnje zbog ponašanja prema otuđenom roditelju - ne pokazuju suosjećanje ili grižnju savjesti za roditelja kojeg odbijaju

6. slaganje s otuđujućim roditeljem pri roditeljskim sukobima - uvijek su na strani otuđujućeg roditelja, bez obzira na to koliko neutemeljeni ili apsurdni njegovi argumenti bili, ne želeći čuti argumente drugog roditelja

7. prezentiranje posuđenog scenarija - često koriste fraze identične onima otuđujućeg roditelja, koriste izraze koje zapravo ne razumiju, ne daju detalje događaja

8. odbacivanje proširene obitelji otuđenog roditelja.

Gardnerova teorija je kasnije naišla na kritike, prvenstveno zbog definiranja dječjeg ponašanja kao »sindroma«, nepostojanja valjanih znanstvenih studija o ovom sindromu, fokusiranosti isključivo na jednog »otuđujućeg« roditelja kao uzroka razvoja dječjih odbijajućih ponašanja, mogućnosti zlouporabe PAS-a kao argumenta od strane zlostavljajućih roditelja kako bi se dobilo skrbništvo nad djecom, itd. (Faller, 1998.; Bruch, 2001.; Kelley i Johnston, 2001.; Johnston i Kelley, 2004.; Walker, Brantley i Rigsbee, 2004.; Emery, 2005., prema Profaca 2013.). Navedeni autori nudili su nadopune Gardnerovih postavki, predložili preimenovanje PAS-a u PA (izbacili »sindrom« iz naziva), razradili njegovu teoriju i potkrijepili je istraživanjima. Unatoč kritikama, Gardnerove postavke i uvođenje pojma manipulacija roditelja tijekom razvoda braka uvelike je doprinijelo i pomoglo boljem shvaćanju roditeljskih i dječjih ponašanja u razvodu braka i omogućilo da se na drugačiji pristup priđe takvim problemima.

Ovaj rad će se prvenstveno zasnivati na Gardnerovim postavkama sindroma otuđenja od roditelja i saznanjima do kojih je došao Warshak tijekom rada s brojnim roditeljima i djecom u razvodu braka. 


\section{SLUČAJ IZ PRAKSE}

Ana i Marko bili su u braku 13 godina, kada je Ana pokrenula tužbu za razvod braka i odselila sa zajedničke adrese. U braku je rođeno dvoje djece, Robert (12 god.) i Marta (7 god.). Povod Aninom odlasku bio je sukob između nje i Marka kada je zatražila i intervenciju policije. Partnerski odnosi bili su narušeni duže vrijeme, Marko je bio izrazito ljubomoran, smetalo mu je što Ana radi noćne smjene (medicinska sestra), optuživao je da se zabavlja na poslu i sl. Ana je nagovještavala svoj odlazak, očekujući promjene u suprugovom ponašanju. Prilikom jedne svađe, kada je Ana otvoreno izrekla svoju odluku da pokrene razvod braka sukob među partnerima je eskalirao, došlo je od verbalnog sukoba, za što su oboje proglašeni krivim na Prekršajnom sudu. Nakon toga, Ana s Martom odlazi iz njihovog stana, dok Robert ostaje s ocem. Kada je Ana odlazila iz kuće, namjeravala je povesti oboje djece sa sobom, međutim, Robert je izrazio želju da ostane s ocem, što je ona u tom času poštovala misleći da će se kasnije ona i suprug dogovarati oko detalja vezanih za roditeljsku skrb. Komunikacija među supružnicima je izrazito poremećena, kako partnerska tako i roditeljska. Ana je inicirala razvod što Marko teško prihvaća, osjeća se jako povrijeđenim, poistovjećuje uloge partnera i roditelja pa tako optužuje Anu da je razrušila obitelj, napustila sina. Marko iznoseći primjedbe na podobnost majke kao argumente iznosi i naglašava činjenicu da je ona pokrenula razvod, dakle, prema njegovom mišljenju, uništila obitelj što za njega podrazumijeva da nije dobra majka, jer dobre majke ne pokreću razvod. Također ističe da Ana radi u noćnim smjenama, izlazi van (ne navodi konkretno što pri tome misli, noćni izlasci ili odlazak na posao) i pri tome ostavlja kćer na čuvanje svojim roditeljima. Robert odmah po razdvajanju roditelja počinje odbijati kontakte s majkom, u potpunosti je odbacuje, okrivljujući je za razvod. Ukoliko i dođe do komunikacije među njima, Robert na vrlo grub način vrijeđa majku. Kada se odselila, Ana nije imala kontakte s Robertom osim nekoliko kratkih telefonskih razgovora u kojima je Robert izražavao svoju ljutnju prema majci. Marko je ustrajan u tome da Robert mora shvatiti kakva je njegova majka (razaračica obitelji). Za vrijeme trajanja bračne zajednice, Robert je imao blizak i topao odnos s majkom, a jednako tako imao je i kvalitetne i redovite kontakte $s$ bakom i djedom po majci. Njegova mržnja prema majci razvila se naglo, bez vidljivog razloga nakon što se majka odselila. Isto tako, naglo je prestao odlaziti i kod bake i djeda po majci, odbijajući bilo kakve kontakte s njima.

$U$ razgovorima s Robertom dobivaju se informacije o njegovim razlozima za takvo ponašanje prema majci. Kao prvi razlog svoje ljutnje prema majci Robert navodi to što je otišla. Zatim naglašava da je mama s njim razgovarala o tome da će se ona i tata razvesti, bez tate, što nije smjela. Također navodi da je tata (koji je nezaposlen) uvijek radio sve po kući, a mama bi spavala. Na upit da li bi mama

\section{0 iskustva iz prakse}


spavala nakon što bi došla iz noćne smjene (medicinska sestra), Robert daje potvrdan odgovor, ali ne mijenja svoj stav. Negira bilo kakve lijepe trenutke s mamom. Ističe da je ona napustila obitelj i da je kriva za razvod. Uporno naglašava da on ima pravo na svoje mišljenje o čemu je čitao i na internetu (stranice pravobraniteljice). Kada opisuje što je to mama napravila a za njega je neoprostivo navodi da mama stalno ostavlja sestru baki i djedu na čuvanje, a ona stalno izlazi van. Kao razlog zašto više ne ide kod bake i djeda navodi da je to zato što svi krive tatu, svi su na majčinoj strani, a ona je ta koja je »stvorila ljutnju«. Ističe da ne postoji ništa što bi mama mogla učiniti da bi on promijenio svoje mišljenje, ne može joj oprostiti. Primjenom psihologijskih instrumenata dobivaju se podaci o potpunom idealiziranju oca i odbacivanju majke.

S druge strane, cijelo vrijeme nakon prestanka zajedničkog života, Marta, koja živi s majkom, redovito odlazi kod oca i brata. Majka redovito odlazi u školu na informacije za Roberta, dolazi u kuću kod Marka vidjeti Roberta, pokušava razgovarati s njim, izbjegavajući bilo kakve rasprave, pita ga kako je, kako je u školi i sl., iako ti susreti obično protječu uz brojne uvrede koje Robert upućuje majci i izbacivanju iz sobe. Spor se vodio samo u odnosu na Roberta, u odnosu na kćer otac se složio da ostane živjeti s majkom, iako je stalno iznosio primjedbe da mu majka onemogućava kontakte, što nije imalo nikakve osnove jer je djevočica redovito odlazila kod oca i brata.

\section{Analiza partnerskog sukoba}

Ana je duže vrijeme osjećala nezadovoljstvo partnerskim odnosima, uzrokovano lošom komunikacijom, razlikama u temeljnim vrijednostima i doživljajima i očekivanjima od braka te je ona kako inicijator prekida ranije prošla faze emotivne i psihološke prilagodbe, kao i suočavanje s krajem odnosa. Za razliku od Ane, Marko je kao ostajući partner zapravo bio zatečen njenim odlaskom te je dugo bio u fazi poricanja i neprihvaćanja razvoda. Nakon te faze, Marko je ušao u fazu ljutnje, kada je svoju povrijeđenost što je ostavljen pretočio u osvetu Ani koristeći se djetetom. Marko je opterećen činjenicom da su se njegovi roditelji razveli, pa sada kada se i sam našao u istoj situaciji, pojačava se njegov osjećaj vlastitog neuspjeha u tom području. Ima vrlo čvrste stavove o tome da djeca razvedenih roditelja nužno imaju poteškoća u prilagodbi i funkcioniranju očekujući da njegova djeca potvrde takva vjerovanja. Izrazito je povrijeđen Aninom odlukom da se razvede, nema kapaciteta da se na odgovarajući način nosi sa svojom boli, već ima izrazitu želju da se osveti Ani i povratno je povrijedi koristeći pritom mlt. Roberta. Marko je preplavljen osjećajima ljutnje i ogorčenosti pa kao najučinkovitiji način da povrijedi Anu vidi u tome da je liši veze s djetetom. 
Komunikacija između partnera je otežana jer, dok se Ana nalazi u kategoriji dijaloga onih koji su sposobni razgovarati i dogovoriti se, Marko je u kategoriji onih koji se svađaju i bore što onemogućava konstruktivno rješavanje njihovog sukoba. lako kao sadržaj sukoba, Marko uporno ističe pitanje roditeljske skrbi, točnije adekvatnost Ane kao roditelja, jasno je da pravi sukob leži u neriješenim partnerskim odnosima i njegovoj nemogućnosti suočavanja s krajem partnerske veze.

\section{Sindrom otuđenja od roditelja}

Uspoređujući ponašanja Marka i Roberta, uočavamo niz faktora koji upućuju na postojanje manipulacije od strane oca i pokušaja otuđivanja od drugog roditelja, odnosno majke, kako to opisuju Gardner (1985.) i Warshak (2008.). Analizirajući manifestacije PAS-a prema Gardneru, možemo vidjeti da mlt. Robert zapravo iskazuje sva navedena ponašanja - mrzi majku i negira bilo kakva pozitivna iskustva s njom, navodi apsurdne razloge i racionalizacije za odbacivanje majke (činjenica da je spavala nakon povratka iz noćne smjene, da izlazi stalno van iako on o tome nema točne informacije, ne zna od kud mu to), idealizira oca, a majci samo ističe mane, naglašava da je sve to »njegovo osobno mišljenje«, da nitko ne utječe na njega, ne pokazuje suosjećanje ili grižnju savjesti u odnosu na majku, stalno je na strani oca i ima potrebu braniti njegove stavove kao jedine ispravne, koristi očeve izraze i fraze, odbacuje širu obitelj po majčinoj strani. Interesantno je naglasiti da kada je otac Marko promijenio svoje mišljenje o Aninom ocu, ističući ga kao jedinog razumnog, i Robert je naglo promijenio svoje mišljenje i ponašanje prema djedu te je jedino s njim počeo održavati kontakte.

U ovom konkretnom slučaju zapravo vidimo »školski primjer« otuđenja od drugog roditelja koji je polučio »izvrsne« rezultate. Majka, koja svojim ponašanjem nije činila ništa što bi doprinijelo održavanju ponašanja Roberta prema njoj, iskazivala je izrazitu brigu, toleranciju, upornost u pokušaju ponovnog uspostavljanja odnosa sa sinom, nije uspjela u pokušaju ponovnog uspostavljanja odnosa sa sinom. Čini se da je utjecaj oca, koji je imao izrazitu želju za osvetom i povredom svoje partnerice, nesposobnost za odvajanjem partnerske uloge od roditeljske, ljutnja koju je prema supruzi osjećao (Warshak, 2008.) bio daleko veći na dijete koji je bio u osjetljivoj razvojnoj fazi (pubertet) i koji se u potpunosti poistovjetio s ocem.

\section{Poteškoće u dokazivanju sindroma otuđivanja od drugog roditelja}

S obzirom da se u ovom slučaju vodio sudski postupak razvoda braka i donošenje odluke o tome s kim će živjeti zajednička djeca, bilo je od iznimne važnosti

\section{2 iskustva iz prakse}


utvrditi kapacitete oba roditelja radi zaštite najboljeg interesa djece. Pri tome su se isticali pokušaji manipulacije od strane oca, što međutim nije nailazilo na prihvaćanje od strane nadležnih institucija. Unatoč detaljnim analizama i iznošenju činjenica (opisima ponašanja i teorijskih postavki), naš sustav, kao i obiteljski zakon, teško prihvaća legitimitet manipulacije kao okvira koji će se uvažavati prilikom odluka o tome s kim će živjeti djeca nakon razvoda braka. Ni u nacrtu novog Obiteljskog zakona ne uvodi se termin manipulacije, već se uvode sankcije za onemogućivanje održavanja osobnih odnosa s djetetom (novčane ili kazna zatvora). Sve dok se u zakonski okvir ne stavi pojam manipulacije kao takav, koji je daleko širi i kompleksniji od jednostavnog onemogućavanja susreta, nailazit ćemo na poteškoće u dokazivanju takvih postupaka od strane jednog ili oba roditelja, a posljedice po djecu bit će i dalje razarajuće. lako je provedeno i psihologijsko-psihijatrijsko vještačenje cijele obitelji kojime je potvrđeno da otac manipulira djetetom te da majka ima veće kapacitete za kvalitetnu skrb o djeci, nije donesena odluka prema kojoj bi djeca nastavila živjeti s majkom. Štoviše, nije se ni inzistiralo na obavezi održavanja redovitih susreta Roberta i majke, zbog uvažavanja činjenice da Robert izrazito odbija te kontakte. Unatoč jasnom stavu centra i nalaza vještaka, sud nije bio sklon uvažiti mišljenja stručnjaka, »skrivajući se« iza Konvencije o pravima djece, naglašavajući potrebu uvažavanja mišljenja djeteta. Čini se da je sud sada doslovno shvatio načela Konvencije o slobodi izražavanja mišljenja djece u takvim postupcima, zanemarujući naglasak na tome da dijete ima mogućnost izraziti svoje mišljenje i da će se ono čuti i uvažiti, ali u skladu s njegovom zrelošću i najboljim interesom. Roditelji su upućeni na terapiju, ali kako se terapija zasniva na dobrovoljnosti i motivaciji samih sudionika, Marko je uglavnom izbjegavao termine te je u konačnici terapija prekinuta. Mlt. Robert je također bio upućen u nekoliko navrata na terapiju, u cilju prevladavanja njegovog negativnog stava prema majci, međutim opet, zbog nedovoljne motivacije Marka i Roberta, terapija nije kontinuirano provođena. Štoviše, otac i sin su se opetovano obraćali pravobraniteljici za djecu zbog »maltretiranja« od strane sustava i prisiljavanje na kontakte s majkom, što je bilo podržano s njihove strane. Na kraju, Robert je nastavio živjeti s ocem, Marta s majkom. Robert nije odlazio na susrete s majkom, izbjegavao je bilo koji način kontakta s njom, dok je Marta i dalje redovito odlazila ocu na susrete i durženja. Ovaj slučaj završio je potpunim otuđenjem djeteta od majke i isključivanjem iz njegovog života što će se zasigurno odraziti na Robertovo funkcioniranje u odrasloj dobi i kvalitetu emotivnih veza koje će imati. Kao što navodi Cummings (1994., prema Profaca, 2013.), posljedice visoko konfliktnih razvoda na djecu manifestiraju se kroz prekid normalnog tijeka razvoja privrženosti, emocionalnu nesigurnost, veću podložnost stresu, slabiju regulaciju emocija, smanjene optimistične procjene sposobnosti suočavanja kod sljedećih sukoba. 


\section{ZAKLJUČAK}

Sindrom otuđenja od roditelja kao oblik manipulacije djecom predstavlja zapravo novi pojam u znanstvenoj literaturi, a zbog nedostatka dovoljnog broja kvalitetnih istraživanja, teško je donositi zaključke. Unatoč tome, ne možemo negirati postojanje ovakvih ponašanja kod određenog broja roditelja u postupcima razvoda braka, najčešće kod onih koji su obilježeni visokom razinom konflikta, odnosno kod onih koji u svoj sukob uključuju i koriste djecu kao sredstvo za pobjedu nad partnerom. Warshak (2008.) u svojoj knjizi navodi: »Možemo razumjeti i suosjećati s partnerom koji se osjeća povrijeđenim i želi osvetu, ili s partnerom koji je preplavljen tjeskobom na pomisao o gubitku djece, ili s onim koji će najradije zaboraviti da je brak ikad postojao. Ali, korištenje djecom za osvetu, za suočavanje s tjeskobom, za brisanje prošlosti je neprihvatljivo. Roditelji se moraju držati nekih viših normi. Moraju imati hrabrosti suočiti se s onim što rade svojoj djeci. Moraju poštovati misiju da štite dobrobit svoje djece, čak i kad ih najmračniji osjećaji tjeraju da zamagle svoju svijest o izdaji te djece. Otrov razvoda mora ostati u boci. Djeca ne zaslužuju ništa manje."

Radi suzbijanja korištenja djece u sukobima roditelja prilikom razvoda braka, potrebno je educirati roditelje vezano za posljedice razvoda braka na djecu, provoditi osmišljeni suportivni tretman djece i obavezno uključivanje roditelja u tretman (radi pružanja podrške roditeljima koji se teško nose s razvodom braka da nađu efikasnije načine rješavanja sukoba). Također je potrebno provoditi dodatne edukacije iz ovog područja svih stručnjaka uključenih u rad s obiteljima, održavati suradnju s obiteljskim sucima te uvesti pravne sankcije (u nadležnosti suda) za roditelje koji provode manipulaciju djece.

\section{4 iskustva iz prakse}




\section{LITERATURA}

1. Ernečić, M. \& Patrčević, S. (2013). Razvod - pogled iznutra. Koprivnica: Udruga za pomoć djeci i mladeži »Prijatelj«.

2. Gardner, R. (1985). Legal and psychotherapeutic approaches to the three types of parental alienation syndrome families. Williamsburg: American Judges Association.

3. Jelavić, M. (2010). Djeca i konfliktni razvodi. U: Osmak Franjić, D. (ur.), Zbornik priopćenja s Godišnje konferencije Mreže pravobranitelja za djecu Jugoistočne Europe i stručnih rasprava pravobranitelja za djecu RH. Zagreb: Pravobranitelj za djecu, 2010.

4. Profaca, B. (2010). Učinci izraženog roditeljskog sukoba tijekom razvoda braka na dijete. U: Osmak Franjić, D. (ur.), Zbornik priopćenja s Godišnje konferencije Mreže pravobranitelja za djecu Jugoistočne Europe i stručnih rasprava pravobranitelja za djecu RH. Zagreb: Pravobranitelj za djecu, 2010.

5. Profaca, B. (2013). Roditeljstvo nakon razvoda braka. Radni materijal s nastave. Zagreb: Studijski centar socijalnog rada, Pravni fakultet Sveučilišta u Zagrebu.

6. Warshak, R. A. (2008). Otrov razvoda. Zagreb: Algoritam. 
Ljetopis socijalnog rada 2014., 21 (1), 169-178 str.

Ljubica Hajnić

Social Welfare Center Zagreb

Office Dubrava

\section{PARENTAL ALIENATION SYNDROME}

\section{SUMMARY}

This paper is occupied by the theme of parental alienation syndrome of children from their parents during and after the divorce as a consequence of conflict among partners. Through the case analysis author will try to show how the parent, partner who hardly deals with the decision of divorce try his/her anger, dissapointing and hurt to pass to child/children and tries to revenge to partner and alienate him/her from children. Author shall problematize the difficulties of evidencining such behaviour on the court and the posssibilities of combating such behaviour (legal consequences)

Key words: parental alienation syndrome, divorce, children. 